\title{
RECENT DEVELOPMENTS IN THE LAW OF PRIVILEGE: R. v. LITTLECHID
}

\author{
MAVIS COXON HAWKEYE*
}

\section{THE CASE}

On November 14, 1979, the Court of Appeal of Alberta handed down the decision in the case of $R$. v. Littlechild. ${ }^{1}$ This decision is indicative of a new trend in judicial thought which, if it continues, will have far reaching effects on the law of privilege in general and on professional communications in particular.

\section{A. Factual History}

Danny Littlechild fraudulently obtained $\$ 31,000$ from his employer's accounts. As a result, in March 1978, he was charged with and subsequently pleaded guilty to two counts of "using a cheque knowing it to have been forged". Some of the money had been taken in cash and travellers' cheques. The remainder was deposited in his account at the Royal Bank in Wetaskiwin and in his wife's chequing account at the Toronto-Dominion Bank in the same city. Upon notification of the charges against Littlechild, the TorontoDominion Bank placed a "freeze" on his savings-chequing account, into which no forgery proceeds had been placed, as well as on Mrs. Littlechild's chequing account. This was a source of some difficulty to the Littlechilds as it prevented access to the funds which were in the bank prior to the forgeries. They consulted a solicitor, who arranged to have Mrs. Littlechild's account "unfrozen" and the proceeds of the forgeries contained in it placed into a separate "suspended" account. Littlechild subsequently contacted the solicitor about gaining access to his savings-chequing account. Littlechild testified that the solicitor told him that he would be notified by telephone if any problem arose in connection with "unfreezing" the account.

The Deputy Clerk of the Court/Deputy Sheriff for the Judicial District of Wetaskiwin, acting as an interviewer for the Alberta Legal Aid Society, interviewed Littlechild on June 28, 1978 regarding his application for legal aid. During the course of this interview Littlechild explained that he lacked sufficient funds to provide for a defence on the forgery charges, his bank accounts having been "frozen" pending the litigation. He then completed and signed the Legal Aid Society's standard application form.

On July 27th and 28th of 1978, Littlechild wrote two cheques for groceries to Canada Safeway Limited - the first for the amount of $\$ 321.11$ and the second for $\$ 120.06$. These cheques were returned to Safeway with the notation "funds not prepared" marked on them. As a consequence of this, Littlechild was charged with two counts of obtaining goods by false pretences under s. 320 of the Criminal Code. ${ }^{2}$ That section provides that:

- LL.B., of the graduating class of 1981, Faculty of Law, The University of Alberta. The author would like to thank Bruce P. Elman for his assistance in the preparation of this article. Professor Elman is currently on leave from The University of Alberta, a visiting professor at the Faculty of Law, Stanford University.

1. R. v. Littlechild [1980] 1 W.W.R. 742, (1979) 11 C.R. (3d) 390.

2. R.S.C. 1970 , c. C-34, as am.. 
1) Everyone commits an offence who:

(A) By a false pretence, whether directly or through the medium of a contract obtained by false pretence, obtains anything in respect of which the offence of theft may be committed or causes it to be delivered to another person.

The two informations, one charging an offence involving over two hundred dollars and the other an offence involving less than two hundred dollars, claimed that the accused had obtained the groceries from Safeway by false pretences and with intent to defraud. The accused pleaded not guilty and elected trial by provincial court judge.

\section{B. Adjudication at Trial}

Both counsel agreed to proceed on the charge relating to the $\$ 321.11$ cheque and then to apply all of the evidence to the other cheque.

The Assistant Manager of Administration for the Wetaskiwin branch of the Toronto-Dominion Bank was called by the Crown to testify that a "freeze" had been placed on the Littlechild accounts on March 3, 1978. She stated that this was automatic bank policy with divisional authorization. The bank would not release funds possibly involved in a pending court case.

The Crown then attempted to tender the evidence of the legal aid interviewer. In the midst of questioning concerning statements made by Littlechild to the interviewer about the availability of funds to procure a defence, Rolf P.C.J. inquired whether Crown counsel would be requesting that information revealed in a confidential legal aid application and interview be allowed in evidence. Although defence counsel (the accused had changed counsel prior to trial) was not concerned about the evidence, the trial judge, upon learning that such questions would be asked, refused to admit the evidence of the interviewer. He explained that he was gravely concerned about the effect that allowing the legal aid interviewer to testify would have on the important institution of state-provided legal services. He further ruled that evidence of this type could only be used in a criminal prosecution involving falsification of the legal aid application and that for other purposes it must remain privileged.

Defence counsel then called the accused. He testified that he had not received a telephone communication from his former solicitor. As a result, he honestly believed that his bank account had been "unfrozen" at the time he had written the cheques.

On cross-examination, Crown counsel elicited an admission from the accused that he had told the legal aid interviewer that his bank accounts were "frozen". Redirect examination clarified that the accused had intended to tell the interviewer that his account at the Royal Bank (which contained the forgery proceeds) was "frozen" and not his Toronto-Dominion account which he used to purchase the groceries.

Defence counsel in his summation brought out two main points. The first was that there had been no proof that the action by the bank was proper. The Assistant Manager for Administration had given evidence that the action was taken after a phone call and a letter. Section 96(4) of the Bank Act ${ }^{3}$ required that a writ, process, or order of injunction made by a court must be presented to a bank before they could unilaterally "freeze" an account. The 
second point was that the Crown had failed to prove fraudulent intent on the part of the accused. According to his unshaken testimony, he believed that his Toronto-Dominion savings-chequing account was "unfrozen" at the time he wrote the cheques.

The Crown contended that the action by the bank should be presumed legitimate unless the defence put forward some evidence that showed otherwise. Counsel also pointed out that al though the accused said his account was free for use, he told the legal aid interviewer that his funds were unavailable. Crown counsel did not mention that the accused had testified that he believed his Royal Bank account containing stolen funds was "frozen" but that his Toronto-Dominion account was not.

Rolf P.C.J. held that in a criminal case which involved the freedom of the subject, it was essential that he be convinced by argument, not opinion, that the bank's action was proper. Courts could not make assumptions in favour of the Crown which could possibly lead to imprisonment of the accused. On the second point he held the accused had believed that his former solicitor had "unfrozen" his account. The accused had been advised by the bank that he had sufficient funds in this account. Consequently, he had no intent to defraud. Rolf $\mathrm{J}$. then reiterated his refusal to allow the legal aid interviewer to testify as to the confidential communications which took place during the interview with Littlechild.

On appeal the Crown sought a new trial on the basis that the learned trial judge erred in excluding the legal aid interviewer's testimony as it was not within any recognized category of privilege.

\section{Arguments on Appeal}

The appeal was argued solely on a question of law, namely, whether communications made during a legal aid interview should be protected by privilege.

The Crown listed the four conditions which Wigmore 4 defined as necessary (and sufficient) for the recognition of a privileged communication. These are as follows:

1) The communications must originate in a confidence that they will not be disclosed;

2) This element of confidentiality must be essential to the full and satisfactory maintenance of the relation between the parties;

3) The relation must be one which in the opinion of the community ought to be sedulously fostered; and

4) The injury that would inure to the relation by the disclosure of the communications must be greater than the benefit thereby gained for the correct disposal of litigation.

An attempt was made by Crown counsel to limit Wigmore's principles to describing the solicitor-client privilege.

The Crown purported to show that the relationship between the legal aid interviewer and a prospective client did not satisfy the criteria for privileged communication. They claimed that the communications were not made in confidence, as the accused had signed the legal aid form which contained certain waiver and release clauses: ${ }^{5}$

WAIVER: In the event that a solicitor is assigned to me under the provisions of the Legal Aid Society of Alberta I hereby waive any legal professional privilege which I have arising

4. J.H. Wigmore, Evidence in Trials at Common Law, Vol. 8 (McNaughton Rev. 1961), para. 2285.

5. Crown Factum, "Materials" section. 
out of any communication passing between the said solicitor and myself, or between the said solicitor and those persons participating in its operation to assess the merits of this application for legal assistance under the Legal Aid Society of Alberta.

RELEASE: I hereby consent to permitting the Legal Aid Society of Alberta, in its discretion, to use any information necessary to verify my application, and hereby authorize the Legal Aid Society of Alberta to obtain information and records which pertain to myself and/or my financial circumstances, from any source whatsoever, as the Legal Aid Society of

Alberta requires in order to determine or review financial eligibility. [emphasis added]

The importance of confidentiality to the satisfactory maintenance of the relationship was also questioned. The Crown claimed that it was not essential to maintain confidentiality in the legal aid program and in fact that "the whole legal aid scheme was premised on this lack of confidentiality". ${ }^{6}$ There is no support in the Crown's factum for this statement, unless it is the waiver and release clauses previously quoted.

The Crown further suggested that the relationship was not one which the community wished to sedulously foster because the legal aid system was designed to discourage confidentiality, with the approval of the Attorney General.

The Crown claimed that the injury to the legal aid program through the risk of disclosure is not greater than the benefit that the information would provide in litigation. Those in need of legal aid would not be less likely to apply for it.

As a final line of argument, the Crown stated that Wigmore's test did not apply to a criminal prosecution, and that the facts of the case did not bring the legal aid interviewer's testimony within any category of privileged communication recognized by Canadian courts in criminal prosecutions. In support of this contention they cited Rumping v.D.P.P. ${ }^{7}$ and R. v.St. Jean. ${ }^{8}$ Halsbury's Laws of England ${ }^{\ominus}$ and Mc Williams on Canadian Criminal Evidence ${ }^{10}$ were also cited. These sources indicate that the privilege of confidential communication applies only to the solicitor-client relationship.

The defence conceded that the relationship was not within the purview of Wigmore's conditions for a claim of privilege. They also allowed that Wigmore's propositions did not apply to a criminal case. However, they did argue that the testimony in question was privileged because it came within the Alberta Rules of Court, Rule 933 (since repealed) which provided that:

Where a legal aid certificate has been issued in favour of a party to any proceedings, the existence of the certificate or of the fact that the person is receiving legal aid under a legal aid plan in those pro. ceedings shall not be disclosed to the court. [emphasis added]

The defence made the alternative assertion that the trial judge had properly exercised his inherent discretion to disallow evidence. This inherent discretion was allegedly confirmed by the Supreme Court of Canada in $R$. v. Wray. ${ }^{11}$

The defence also sought to uphold the decision on the basis that no substantial wrong or miscarriage of justice had occurred. The accused confessed in

6. Crown Factum at 7 .

7. [1962] 3 All E.R. 256.

8. (1976) 34 C.R.N.S. 378.

9. 11 Halsbury's Laws of England (4th ed.), para. 464.

10. McWilliams, Canadian Criminal Evidence (1974) at 574-585.

11. [1971] S.C.R. 272. 
his testimony that he had told the legal aid interviewer he did not have access to his funds, and he had explained his reason for doing so.

D. Adjudication in the Court of Appeal of Alberta

After presenting the facts in the case, Laycraft J.A. went on to discuss the general rule of solicitor-client privilege. He confirmed that a trial judge has a duty to step in and claim the privilege for a client where the solicitor does not do so, and complimented the trial judge for having done so. ${ }^{12}$

Laycraft J.A. then stated that "the test for the establishment of a privilege $\ldots$ in a given relationship is that set forth in 8 Wigmore on Evidence, pargraph 2285". ${ }^{13}$ He outlined the four conditions mentioned above, and then applied them to the case before him. He commented that a legal aid applicant will likely believe that what he says in his interview will not be disclosed. Further, confidentiality is necessary to maintain the satisfactory functioning of the legal aid scheme. According to Laycraft J.A., "it is clearly in the interest of the community that the conditions essential to the function of the system should be fostered" ${ }^{14}$ and that the injury to the legal aid system from disclosure is sufficiently serious to warrant the exclusion of evidence; the benefits would not outweigh this even in "those rare instances where disclosure would serve any purpose". ${ }^{15}$

Wheeler v.Le Marchant ${ }^{16}$ and Lyell $\mathrm{v}$.Kenned $y^{17}$ were used to support the principle that both the client and the solicitor can act through representatives and still claim privilege for the communications. It was not significant that the interview concerned an attempt to retain counsel rather than actual advice given in contemplation of litigation. Therefore, conversations with a solicitor's agent could also be described as privileged - regardless of whether the solicitor was ever retained.Laycraft J.A. asserted that this principle applied to protect conversations between legal aid interviewers and prospective recipients of legal aid.

The court assessed the waiver clause as having a very limited application. It was only designed to enable the Legal Aid Society to discover unwarranted claims for assistance, and did not deprive the legal aid applicant of the protection of confidential communications provided by the common law.

\section{DEVELOPMENT OF THE PRIVILEGE ON CONFIDENTIAL COMMUNICATIONS}

For a solicitor to effectively present his client's case, he must have knowledge of all the relevant facts. This will only come about if the client can be assured that his disclosures to the solicitor will not be used against him. This theory was confirmed in Wright v.Mayer ${ }^{18}$ wherein Lord Eldon stated that the privilege was not that of the solicitor, but of the client and the public. Ori-

12. Supra n. 1 at 746, 394, affg. Bell v. Smith [1968] S.C.R. 664 and Beer v. Ward (1821) 37 E.R. 799.

13. Supra n. 4.

14. [1980] 1 W.W.R. 742 at 748 .

15. Id..

16. (1881) 17 Ch.D. 675.

17. (1884) 27 Ch.D. 1.

18. (1801) 6 Ves. 281,31 E.R. 1051 (Ch.). 
ginally, the privilege had not been functional in preventing access to confidential communications because the client could be called to testify in respect of them. Once the above theory was accepted, the client was exempt from testifying as to communications involved in the particular litigation.

As the privilege belonged to the client, he could prevent his solicitor from disclosing information. In Beer $\mathrm{v}$. Ward ${ }^{10}$ it was held that a solicitor could not employ knowledge gained at the client's expense against him - it became the property of the latter. Furthermore, although it must be taken for granted that a solicitor would act in his client's best interests and claim the privilege, if he did not, it was the duty of the court to step in and claim it for him. A solicitor must claim the privilege for a former client as well. Not to do so would be improper unless the solicitor had notice that the privilege had been waived. Beer v. Ward, as well as the case of Bell v. Smith ${ }^{20}$, was cited in the Littlechild case to confirm the trial judge's duty to assert the privilege for the accused when counsel failed to do so.

The American Model Evidence Code provides that the client must claim the privilege. Therefore the judge is under no duty to enforce it of his own motion, although he may inform an ignorant witness if he wishes..21 The policy in Littlechild would appear to be fairer as it does not penalize ignorance. Doubtless the latter will remain the law in Canada.

Greenough v. Gaskell ${ }^{22}$ in 1833 pointed out that the restriction of the client's privilege to communications involving the case at bar was inconsistent with the rationale of safe resort to solicitors - a communication was hardly safe if it could be used against the client in subsequent litigation. Those communications encompassed by the privilege began to expand. First the communications were protected in subsequent litigation. ${ }^{23}$ Then it was held that the communications need only relate to a matter involving contemplated litigation, or a matter in dispute. ${ }^{24}$ Wheeler v. Le Marchant ${ }^{25}$ and Minet v. Morgan ${ }^{26}$ were used by Laycraft J.A. to establish that seeking legal advice from a professional advisor in a professional capacity, although not related to actual or contemplated litigation, was sufficient to support a claim of privilege. Therefore, it was no bar to the accused's privilege that he was seeking to retain counsel rather than actually preparing his defence. Promoting confidence in the relationship as to pre-dispute communications served to promote preventative action on the part of clients and allowed solicitors to help keep the court system efficient.

The modern rule of solicitor-client privilege is aptly summed up in 8 Wigmore on Evidence: ${ }^{27}$

Where legal advice of any kind is sought from a professional legal advisor in his capacity as such, the communications made relevant to that purpose, made in confidence by the client are at his instance permanently protected from disclosure by himself or by the legal advisor, except the client waives the protection.

19. (1821) 37 E.R. 799.

20. [1968] S.C.R. 664 .

21. American Law Institute Model Evidence Code, Rules 204, 210.

22. (1833) 39 E.R. 618, cited in supra n. 1 at 747, 394-395.

23. Pearce v. Foster (1885) 15 Q.B.D. 114.

24. Clark v. Clark [1830] 1 M. \& W. 2(3).

25. Supra n. 16.

26. (1873) 8 Ch.App. 361 .

27. Supra n. 4 at para. 2292. 
Lord Buckmaster in Minter v.Priest ${ }^{28}$ held that there is no rigid definition of the subject to be discussed in order for professional privilege to apply the conversation need only be "fairly referable to the relationship". Wigmore says that anything concerning rights and obligations which is committed to a legal advisor is prima facie for a legal purpose. Whatever facts the client felt were necessary to discuss will be considered relevant to the purpose, and protected by privilege. In Littlechild it would appear that financial discussions were relevant to obtaining counsel under the legal aid plan. Therefore, these communications came within the parameters of the privilege.

Early in the history of the solicitor-client privilege it was recognized that solicitors required support staff in order to function. In Lyell v. Kenned $y^{20}$ it was held that the privilege applied to statements made to the solicitor or anyone who could be properly treated as an agent of the solicitor. Persons who could be treated as agents were those who were employed by the solicitor, such as his clerk. Third parties retained by the solicitor to give information for preparation of litigation could also be treated as agents of the solicitor. Wheeler v. Le Marchant ${ }^{30}$ established that the client could act through an agent employed to obtain legal advice or to aid in preparation for trial. A third party used by the client to explain a factual situation to the lawyer is an agent obtaining legal advice. ${ }^{31}$

The fact that communications are made within a privileged relationship does not mean that testimony regarding them is barred. If the communication was made in furtherance of a crime or a tort, either the solicitor or the client can be compelled to disclose it. ${ }^{32}$ However, a mere allegation of fraud will not be sufficient to displace the prima facie right to protection of professional confidences. ${ }^{33}$ The allegation must be supported by some evidence or admission. ${ }^{34}$

As the privilege is provided for the client's benefit, he may waive it. "If the client chooses to withdraw the veil, the law interposes no further difficulty. The communications are then available as evidence." ${ }^{35}$ Waiver may occur expressly or by implication. Testimony offered as to specific communications or any part thereof operates as a waiver in regard to all other communications on the same matter ${ }^{36}$ Once privilege has been waived on a communication at the trial stage it remains waived for all further stages and subsequent litigations. $^{37}$

Professional privilege is designed so that a litigant may put his full case before his solicitor without fear that the confidences may become public. Bits and pieces of communications cannot be taken out of context and used to

28. [1930] A.C. 558.

29. Supra n. 17.

30. Supra n. 16.

31. Susan Hosiery v. M.N.R. [1969] 2 Ex.C.R. 27.

32. The Queen v. Cox and Railton (1884) 14 Q.B.D. 153.

33. Bullivant v. A.G. Victoria [1901] A.C. 196.

34. Id..

35. Minter v. Priest, supra n. 28.

36. Wigmore, supra n. 4 at para. 2327.

37. Id. at para. 2328. 
the detriment of the client. ${ }^{38}$ In Pearce v. Foster, Brett M.R. stated that: ${ }^{39}$

The reason of the privilege is that there may be that free and confident communication between solicitor and client which lies at the foundation of the use and service of the solicitor to the client[.]

Jessel M.R. claimed that the privilege was of a very limited character, extending only to obtaining the assistance of lawyers. ${ }^{10}$ Wigmore wrote that the privilege was: ${ }^{11}$

... worth preserving for the sake of a general policy, but it is nonetheless an obstacle to the investigation of truth. It ought to be strictly confined within the narrowest possible limit consistent with the logic of its principle.

The American Model Evidence Code aptly explained the need for the solicitor-client privilege as follows: ${ }^{42}$

The privilege is no longer that of the lawyer, but that of the client. And the continued existence of the privilege is justified on grounds of social policy. In a society as complicated in structure as ours and governed by laws as complex and detailed as those imposed on us, expert legal advice is essential. To the furnishing of such advice the fullest freedom and honesty of communication of pertinent facts is a prerequisite. To induce clients to make such communications the privilege to prevent their disclosure is said by the courts and commentators to be a necessity. The social good derived from the proper performance of the functions of lawyers acting for their clients is believed to outweigh the harm that may come from the suppression of the evidence in specific cases.

Attempts to restrict the scope of the solicitor-client privilege have failed. New developments in case law, such as the Littlechild case, indicate that the categories of privilege for confidential communications are not static.

The reasonableness of extending protection to confidences involved in professional relationships other than that of solicitor-client was mentioned as far back as Greenough v. Gaskell ${ }^{43}$ in 1833 . Brougham L.C. claimed that"certainly it may not be very easy to discover why a like privilege has been refused to others, and especially to medical advisors". In Wilson v. Rastall, ${ }^{44}$ Buller T. stated that it was lamentable that the privilege had not been extended, especially to medical advisors who were obliged to disclose information obtained while attending their professional capacity. Other cases have vacillated between extending the confidential communication to other relationships and restricting it to the solicitor-client relationship.

\section{SIGNIFICANCE OF THE LITTLECHILD CASE}

$R$. v. Littlechild is an important case for its treatment of agency principles in the area of solicitor-client privilege. Also, it is part of a recent trend to apply balance of interest criteria to determine the existence of a privilege. The Littlechild case has affirmed that the trial judge has a duty to protect a client's privilege. The case seems to have done away with at least one form of waiver of privilege by implication. Overall, the case expands the protection for confidential communications.

The Littlechild case may have broadened the scope of agency principles as they relate to the solicitor-client privilege. McCormick states that agency is

38. Susan Hosiery v.M.N.R., supra n. 31.

39. Supra n. 23 at 120.

40. Wheeler v. Le Marchant, supra n. 16.

41. Supra n. 4 at para. 2291.

42. Supra n. 21 at 146-147.

43. Supra n. 22.

44. [1972] E.R. 1287. 
established where the relationship is "the way business is generally done"45 and if the presence of the agent is reasonably necessary to the professional relationship. Lederman maintains that if the third party must consider and act upon the information prior to retention of a solicitor he is not a mere agent and no privilege attaches. ${ }^{46}$ Both the Uniform Rules of Evidence ${ }^{47}$ and the Proposed Evidence Code ${ }^{48}$ speak of privilege attaching to communications made to a representative of a solicitor who is employed by him to assist in rendering legal advice. Laycraft J.A. states:48

It follows from the authorities referred to above that conversations with a solicitor's agents held for the purpose of retaining him would also be privileged, even though the solicitor was not then, or ever, retained. In my view the principle protects from disclosure a conversation between an applicant for legal aid and the non-lawyer official of the Legal Aid Society who interviews him to see if he is qualified.

The authorities above-mentioned seem to indicate that an agency relationship between a legal aid interviewer and a solicitor retained by the Legal Aid Society does not exist. The solicitor does not employ the interviewer as is required by the Lyell case, ${ }^{50}$ The Uniform Rules, ${ }^{51}$ and the Proposed Evidence Code. ${ }^{52}$ The interviewer is not subordinate to the solicitor and does not act under the latter's direction. In fact, the statement by Lederman would place the interviewer outside an agency relationship because he must consider the information given in the interview and then decide whether or not to make a referral. An argument could be made on the basis of $R$. v. Chone ${ }^{53}$ that the interviewer represents himself as an agent of the solicitor by performing his referral function. A client would reasonably believe the interviewer to be an agent because it is necessary to see him prior to seeing the solicitor. It is doubtful that the accused in the Littlechild case would have given financial information to the interviewer if he had not believed that the interviewer had a substantial connection with a solicitor.

The principle that an agent must be a subordinate employee of the solicitor should be dispensed with. As the decision in $R$. v. Littlechild indicates, it is no longer applicable in modern society. Lyell v. Kennedy was decided at a time when legal aid programs did not exist. For the Legal Aid Society's referral program to function efficiently, it is necessary to employ interviewers. If the interviewers are required to clear their decisions through solicitors, the purpose of the system is frustrated. An extension of agency to legal aid interviewers is warranted because it is the way business must be done in order to achieve the objectives of a legal aid system. The Littlechild case allows this extension.

The legal aid interviewer might also be seen as an agent of the client. The interviewer is used to present a factual situation (the applicant's predica-

45. McCormick, Handbook on the Law of Evidence (1954).

46. S.N. Lederman, "Private Privileges", presented at the Seminar for Alberta District Court Judges, December 3, 1976.

47. Uniform Rules of Evidence (1975) (U.S.).

48. Law Reform Commission of Canada, Proposed Evidence Code.

49. [1980] 1 W.W.R. 742 at 750-751.

50. Supra n. 17.

51. Supra n. 47.

52. Supra n. 48.

53. (1908) 13 C.C.C. 289. 
ment and financial state) to the solicitor, thus meeting the requirements of Susan Hosiery v. MNR. ${ }^{54}$ If "employed" is expansively defined to include "used", then the interviewer is someone employed to aid in preparation for trial (by finding the applicant a solicitor). Wheeler v. Le Marchant indicates that this is sufficient to establish an agency relationship..$^{\mathrm{s}}$

However, it is not necessary to validate the Littlechild decision by bringing the interviewer-client relationship within the solicitor-client privilege by means of the agency of the interviewer. The court did not rest its decision on agency, but on the four Wigmore principles. Satisfaction of these was sufficient to establish a privilege respecting confidential communication, with or without agency.

Several recent cases ${ }^{36}$ indicate that the courts are willing to apply Wigmore's principles to communications made in confidence and to documents, briefs and statements made to prepare for litigation. How will they use those principles to evaluate whether a particular relationship merits the protection of a privilege on confidential communications? $R$. v. Littlechild and the prior cases of $D$. v. National Society for the Prevention of Cruelty to Children $^{57}$ and Slavutych v. Baker ${ }^{88}$ indicate that some form of balance of interest test will be used to determine whether privilege will apply to a given relationship. However, other cases emphasize confidentiality - if the layman would believe that his communications could not be disclosed, then they should be protected.

G. v. G. ${ }^{5 \theta}$ stated that courts should not admit in evidence communications which a layman would believe are privileged. The court acknowledged that in order to receive proper treatment, a patient must confide freely in his psychiatrist. In many cases, patients would not so confide unless they knew their communications would remain confidential. $R$. v. Hawke ${ }^{60}$ discussed the "right to privacy of a witness", the right to prevent disclosure of a communication made in circumstances the ordinary citizen would consider confidential.

There has been resistance to this trend. In Cronkwright $\mathrm{v}$. Cronkwright, ${ }^{61}$ Wright J., referring to $G$. v. G., claimed that public views as to privileged communication should not prevail against the overpowering necessity for fair and open administration of justice. The protection of privilege could be expanded too far, as it was in the 1700's when a promise of secrecy would suffice to protect communications.

The exclusion of evidence under the rubric of a privilege is not done because of problems inherent in the evidence, but for social policy reasons. When does the need for privacy in a relationship outweigh the need for truth

54. Supra n. 31.

55. Supra n. 16.

56. See Slavutych v. Baker [1976] S.C.R. 254; Strass v. Goldsack [1975] 6 W.W.R. 155; Medicine Hat Greenhouses v. R. [1979] 1 W.W.R. 296.

57. [1977] All E.R. 589.

58. Supra n. 56.

59. [1964] O.R. 361.

60. [1974] 3 O.R. (2d) 210.

61. [1970] 3 O.R. 784. 
in order to properly dispose of litigation? A balancing test seems to be the most likely approach.

In 1963, Denning M.R. in Attorney-General v. Mulholland ${ }^{62}$ held that questioning professionals as to confidential communications should only be allowed where the answer will be relevant, and the question proper and necessary in the course of justice. Donovan L.J. held that the trial judge need not compel disclosure where it would do more harm than good. In $D$. v. The National Society for the Prevention of Cruelty to Children, ${ }^{63}$ Denning M.R. refused to compel the Society to disclose an informant's name because the public interest in excluding the evidence was greater than the public benefit gained by its admission. He felt that the Society's information sources might dry up if they feared that their names might be disclosed. However, the majority in that case held that the information could not be kept out of legal proceedings as it did not fall within a recognized category of privilege.

$R$. v.Littlechild combines the perceived confidentiality or "common sense" approach with a balancing test by using the Wigmore criteria. Laycraft J.A. described this as the test to determine compellability of disclosure of communication in a "given relationship". He did not restrict it to solicitor-client or other professional relationships.

Many American states have enacted the Uniform Rules of Evidence ${ }^{64}$ which provide specific categories of relationships which will be covered by privilege. These include the doctor-patient, psychotherapist-patient, and the religious advisor privilege. The Quebec Civil $\mathrm{Code}^{65}$ and the Newfoundland Evidence $A c t^{66}$ provide for the spiritual advisor privilege. They are oddities in that the privilege belongs to the clergyman and not to the communicator. The American Federal Rules of Evidence have moved away from the category formula, requiring that "privilege shall be governed by the common law as interpreted by United States courts in the light of reason and experience". ${ }^{67}$ This rule seems to be a retrograde step as the application of privilege is completely uncertain. The Law Reform Commission's Proposed Evidence Code ${ }^{68}$ codifies the solicitor-client privilege in a different form than the present common law privilege. In order to be protected, consultation with a solicitor must be in contemplation of litigation. ${ }^{69}$ Briefs prepared for litigation, or the solicitor's "work product" wo will not be protected if the probative value substantially outweighs the disadvantages of disclosure, and the information is not reasonably available from any other source. ${ }^{71}$ This latter principle indicates that the Law Reform Commission would agree with the Strass v. Goldsack approach to disclosure of briefs prepared for litigation, although some authors believe that it was inappropriate. ${ }^{72}$

62. [1963] All E.R. 767.

63. Supra n. 57.

64. Supra n. 47.

65. 1965 , vol. 2, Art. 308.

66. R.S.N. 1970, c. 115 , s. 6.

67. Federal Rules of Evidence (1975) at R. 501.

68. Supra n. 48.

69. Id. at s. $42(1)$.

70. Hickman v. Taylor (1947) 329 U.S. 495,67 S.Ct. 385.

71. Supra n. 48 at s. $42(2)$.

72. Lederman, supra n. 46. See also Levy, Recent Developments in the Law of Privilege, Workshop, Feb. 28, 1977. 
The Proposed Evidence Code also creates a professional relationship privilege. This is found in s. 41, which states:

A person who has consulted a person exercising a profession for the purpose of obtaining professional services, or who has been rendered such services by a professional person, has a privilege against disclosure of any confidential communication reasonably made in the course of the relationship, if in the circumstances, the public interest in the privacy of the relationship outweighs the public interest in the administration of justice.

Legal advice sought for a purpose other than contemplated litigation would be subsumed by this rule. This provides a balance of interest test, using public interest in the maintenance of the relationship, rather than the injury to the relationship itself, to balance the need for truth in the administration of justice.

The categorial approach provides the greatest certainty, whereas the balancing approach allows for flexibility. For example, the greater portion of society would probably feel that confidentiality in the psychotherapistpatient relationship should be maintained. As Bourdeaux ${ }^{73}$ explains, threat to secrecy prevents effectual treatment. People must feel free to discuss with the therapist everything that concerns them. ${ }^{74}$ If patients realized that there was a danger that their problems might be revealed, few of them would seek help for alcoholism, drug abuse, and criminal compulsions. One analyst has also suggested that psychotherapists' evidence might not be useful in determining truth, as they are not always dealing with communication which reflects objective reality. ${ }^{75}$

What other relationships are to be protected by privilege? It is unlikely that an extension to the bartender-drunk relationship would be warranted. What of the spiritual advisor? Some would see the compelling of disclosure as suppression of religion. ${ }^{76}$ Others may feel that allowing this privilege favours religious people over those with no religious affiliation.

The informant-journalist relationship is important in modern society. Investigative reporting, which requires informers, can prevent tyranny by government and corporations. If journalists can be compelled to reveal their informers' confidences, their sources of information may dry up. On the other hand, a privilege protecting informants from disclosure may encourage irresponsible journalism. Unwarranted statements could not be discovered because journalists could claim privilege when confronted on the issue.

Expansion of the privilege is met with reluctance to proliferate the areas it covers because it is an obstacle in the search for truth. It is not applied because there is some degree of untrustworthiness or prejudicial effect or irrelevancy in the evidence. Its "sole warrant is the protection of interests and relationships which, rightly or wrongly are regarded as of sufficient social importance to justify some incidental sacrifice of sources of facts needed in the administration of justice". ${ }^{77}$ Although courts would get a fuller

73. T. Bourdeaux, "Article V Privileges" (1975) Association of Trial Lawyers of America.

74. Hayman, "Psychoanalyst Subpoenaed" in The Lancet (England, October 16, 1975) at 785-786, cited in 2 Schiff, Evidence in the Litigation Process, (1978).

75. Id.

76. Wigmore, supra n. 4 at para. 2285.

77. McCormick, supra n. 45 at 150. 
picture and, in some cases, much closer to the truth without privilege, it is designed to protect certain relationships. These relationships are judged by society to be more important than the need for full disclosure in individual cases.

Laycraft J.A.'s use of the Wigmore principles has created some uncertainty. What relationships will be allowed confidential communication? Wigmore's principles are value-laden. Individual judges will attach differing degrees of importance to the same relationship, and apply different ideas about the importance of the evidence to the resolution of the dispute. However, both certainty and flexibility are desirable objectives - the law must not change so quickly that no one knows what it is, yet it must keep in step with the times. The principles set forth in the Littlechild case will be defined and limited in subsequent cases. As Clement J.A. stated in Strass v. Goldsack:78

To me the sanction given to these four conditions provides a most useful and helpful rationale which should serve well the general public interest in determining such claims. Not only does it provide a rationale: it also leaves room by the third and fourth conditions for adaptation of the principle to changing needs and conditions of society which is essential to the proper function of the common law.

Inherent in Wigmore's criteria are benefit to the community and fairness in the administration of justice. This is evident from the operation of the principles in the Littlechild case. It is important to have confidence in a legal aid interviewer, as an applicant must tender all relevant information before he can be accepted into the program. To hold that the relationship could not benefit from the protection of privilege would be tantamount to denying the poor the same treatment within the justice system which wealthier people receive. The latter can go directly to their solicitors and claim the protection of privilege for any communications regarding their cause.

The Littlechild case has also expanded the scope of privilege by narrowing the doctrine of waiver by implication. Privilege is designed as a shield to protect communications, not as a sword to allow in evidence favourable parts of a communication and to leave out those which do not support the cause. If testimony is given on direct examination involving privileged communication, then the remainder of the consultations on the same topic are subject to testimonial compulsion. McCormick states that where a party is questioned on cross examination regarding confidential communications: ${ }^{79}$

Unless there are some circumstances which show that the client was surprised or misled, it seems that the usual rule that the client's failure to claim the privilege, when to his knowledge testimony infringing it is offered would apply here, and that the decided cases treating such testimony on crossexamination as being involuntary and not constituting a waiver are hardly supportable.

As Hardin and Faller ${ }^{80}$ explain, once a significant part of the communication has been disclosed, waiver has occurred because the underlying basis for the privilege is gone - the injury to the relationship has been done.

On cross-examination at trial, Littlechild admitted that he had told the interviewer that his bank funds were unavailable. This testimony infringed the privilege; in fact, it was probably the same as the testimony of the legal aid interviewer which had not been allowed in evidence. It was a significant part of the communication between Littlechild and the interviewer. There-

78. Supra n. 56 at 160 .

79. McCormick, supra n. 45 at 197.

80. "Article V Privileges" (1975) Association of Trial Lawyers of America. 
fore, Littlechild could have been considered to have waived the privilege by implication. Once a communication has been waived at one stage of litigation it is waived for all other stages and for all other litigations. Therefore, if the court had considered that a waiver had occurred the case could have been sent back to trial.

Although waiver by implication was not argued in the case (only express waiver, by virtue of the application form's waiver and release clauses, was argued) it seems unlikely that the learned justices missed the point. It is more likely that they felt that in order for a waiver by implication to be voluntary, the accused must have recognized the consequences of what he was saying. Most laymen do not understand the consequences of waiving privilege on a confidential communication.

\section{CONCLUSION}

The Littlechild case will likely be followed as confirming the application of Wigmore's four principles to the determination of privilege. In Canada these principles will be applied to professional communications $(R$. v. Littlechild), to other confidential communications (Slavutych v.Baker ${ }^{81}$ ), and to requests for the production of documents (Strass v. Goldsack ${ }^{82}$; Medicine Hat Greenhouses v. $R .^{83}$ ). Codification of Wigmore's principles so that communications covered by privilege remain dynamic, but with specific categories of relationships and communications defined to provide greater certainty, would be a positive step for legislation.

The principles of agency and waiver for the purpose of privileged communications have also been expanded. The duty of a trial judge to enforce the privilege has been confirmed. If $R$. v. Littlechild is followed, it will allow greater protection for relationships that the public regards as more important than the disposal of a particular litigation.

81. Supra n. 56.

82. Id..

83. Id.. 